\title{
O restrukturyzacji zadłużenia podmiotów prowadzących gospodarstwa rolne
}

\section{Uwagi ogólne}

W dniu 8 lutego 2019 r. weszła w życie ustawa z 9 listopada 2018 r. o restrukturyzacji zadłużenia podmiotów prowadzących gospodarstwa rol$n^{1}$. Ustawa ta zawiera szczególne rozwiązania umożliwiające częściowe uregulowanie zadłużenia związanego z prowadzeniem działalności rolniczej. Jak wskazano w uzasadnieniu do projektu ustawy, mieszkańcy wsi zdecydowanie rzadziej zadłużają się niż mieszkańcy miast, jednak kwota zaległych zobowiązań mieszkańców wsi w ostatnich latach zdecydowanie wzrosła; ponad 20\% zarejestrowanych w Krajowym Rejestrze Długów zobowiązań dotyczy banków i instytucji finansowych. Stwierdzając, że obowiązujące dotychczas rozwiązania, a w szczególności ustawa z 15 maja 2015 r. - Prawo restrukturyzacyjne, która umożliwia tylko częściową restrukturyzację zadłużenia, nie są unormowaniem wystarczającym, uznano za konieczne wprowadzenie nowych, nieznanych jeszcze rozwiązań ${ }^{2}$. Uzasadnione jest więc podjęcie rozważań dotyczących restrukturyzacji zadłużenia podmiotów prowadzących gospodarstwa rolne i sformułowanie ich oceny.

Rozważania te warto jednak poprzedzić dwojakiego rodzaju uwagami. Pierwsze, historyczne, dotyczą szczególnego ustawodawstwa z okresu dwudziestolecia międzywojennego zawierającego rozwiązania o charakterze restrukturyzacyjnym adresowane do podmiotów prowadzących gospodar-

* Naczelny Sąd Administracyjny, Warszawa.

${ }^{1}$ Ustawa z 9 listopada 2018 r. o restrukturyzacji zadłużenia podmiotów prowadzących gospodarstwa rolne (Dz. U. z 2019 r., poz. 33).

${ }^{2}$ Uzasadnienie projektu ustawy z 9 listopada 2018 r. o restrukturyzacji zadłużenia podmiotów prowadzących gospodarstwa rolne, LEX. 
stwa rolne. Drugie odnoszą się natomiast do obowiązującego ogólnego prawa restrukturyzacyjnego i relacji, jakie zachodzą między nim a ustawą z 9 listopada 2018 r. o restrukturyzacji zadłużenia podmiotów prowadzących gospodarstwa rolne. Dopiero wówczas można uzyskać właściwą perspektywę do oceny przyjętych rozwiązań.

\section{Uwagi historyczne}

W okresie dwudziestolecia międzywojennego ukształtowało się szczególne ustawodawstwo o charakterze restrukturyzacyjnym adresowane do osób prowadzących gospodarstwo rolne. Było ono w ówczesnej literaturze

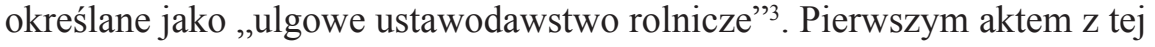
grupy jest rozporządzenie Prezydenta RP z 23 sierpnia 1932 r. o zapobieganiu skutkom trudności płatniczych w rolnictwie. Jego adresatami byli właściciele, użytkownicy, a także dzierżawcy gospodarstw rolnych, z tym że do osób wpisanych do rejestru handlowego ta regulacja nie miała zastosowania.

Rozporządzenie wprowadzało i regulowało dwie instytucje: odroczenie wypłat i postępowanie układowe. O odroczeniu wypłat na jednoroczny okres gospodarczy orzekał sąd okręgowy na wniosek dłużnika lub wierzyciela. Odroczenie wypłat mogło nastąpić, gdy prowadzący gospodarstwo rolne posiadał dostateczny majątek do całkowitego zaspokojenia wszystkich wierzycieli, a który wskutek wyjątkowych i niezależnych od niego okoliczności zaprzestał wypłat lub przewidywał w najbliższej przyszłości konieczność czasowego ich zaprzestania. Instytucja odroczenia wypłat nie mogła być stosowana do wszystkich zobowiązań dłużnika. Ustawodawca wyłączył z niej pewne kategorie, takie jak: zobowiązania o charakterze publicznoprawnym, bieżące opłaty na ubezpieczenia społeczne, należności zabezpieczone zastawem, należne raty z pożyczek długoterminowych udzielanych przez banki państwowe lub instytucje długoterminowe zabezpieczone na nieruchomości. Konsekwencją odroczenia było poddanie kontroli sądu sposobu sprawowania zarządu gospodarstwem rolnym, a także przyjęcie przez dłużnika pewnych ograniczeń w rozporządzaniu gospodarstwem rolnym.

Drugą instytucją było postępowanie układowe. Mianowicie w przypadku, gdy przed upływem 12 miesięcy od wydania wyroku stanowiącego o odroczeniu wypłat dłużnik przewidywał, że nie będzie mógł zaspokoić wszystkich wierzycieli, powinien był w sądzie, który zezwolił na odrocze-

${ }^{3}$ E. Kremer, Odpowiedzialność za zobowiąania zwiazane z prowadzeniem gospodarstwa rolnego, Kraków 2004, s. 287 i n. 
nie wypłat, złożyć - pod rygorem uchylenia odroczenia wypłat - wniosek o otwarcie postępowania układowego. Otwarcie postępowania układowego powodowało z mocy prawa dalsze przedłużenie terminu odroczenia wypłat, ze wszystkimi jego skutkami, aż do chwili zawarcia układu przez sąd. To postępowanie układowe miało ograniczony zakres przedmiotowy, gdyż dotyczyło tylko długów rolnych, a ponadto można było z niego skorzystać jedynie po uprzednim odroczeniu wypłat przez sąd. Należy jednak podkreślić, że w tym okresie brakowało w Polsce powszechnych przepisów o postępowaniu układowym. Takie przepisy pochodzą dopiero z 1934 r. $^{4}$, tym samym postępowanie układowe dotyczące długów rolnych uregulowane w rozporządzeniu z 23 sierpnia 1932 r. miało niewątpliwie nowatorski charakter.

Drugim istotnym aktem prawnym zaliczanym do grupy ulgowego ustawodawstwa rolnego jest rozporządzenie Prezydenta RP z 24 października 1934 r. o konwersji i uporządkowaniu długów rolniczych ${ }^{5}$. Regulowało ono zarówno problematykę konwersji długów rolniczych, jak i problematykę postępowania układowego i likwidacyjnego ${ }^{6}$. Termin „,konwersja długu” nie było jednoznaczne, często kryły się pod nim zjawiska, których kwalifikacja prawna bywała różna. W życiu gospodarczym konwersja oznaczała zazwyczaj przekształcenie jednego długu w inny, mniej uciążliwy dla dłużnika?

W powołanym rozporządzeniu z 24 października 1934 r. możliwość dokonania konwersji długu w swym podstawowym, ogólnym założeniu została oparta na konstrukcji umownego wstąpienia osoby trzeciej w prawa zaspokojonego wierzyciela z art. 178 pkt 2 Kodeksu zobowiązań. Mianowicie dłużnik sam spłacał wierzyciela sumą pożyczoną od osoby trzeciej, w zamian za to mógł podstawić osobę trzecią $\mathrm{w}$ prawa wierzyciela. A zatem chcąc się pozbyć jednego uciążliwego długu, dłużnik zaciągał drugi dług mniej uciążliwy, ale korzystający z tych samych zabezpieczeń. Rozporządzenie zawierało również takie rozwiązania, jak: zawieszenie do 1 października 1938 r. wymagalności wszelkich długów powstałych przed 1 lipca 1932 r., rozłożenie na 28 równych rat zapłaty za długi, których płatność już nastąpiła lub miała nastąpić przed 1 kwietnia $1935 \mathrm{r}$. Z prawnego punktu widzenia są to najprostsze rozwiązania, a ich skutki ekonomiczne obciążały przede wszystkim wierzycieli długów rolniczych.

${ }^{4}$ Rozporządzenie Prezydenta Rzeczypospolitej z 24 października 1934 r. - Prawo upadłościowe (t.j. Dz. U. z 1991 r., Nr 118, poz. 512 ze zm.).

${ }^{5}$ Rozporządzenie Prezydenta RP z 24 października 1934 r. o konwersji i uporządkowaniu długów rolniczych (Dz. U. z 1936 r., Nr 5, poz. 59).

${ }^{6}$ E. Kremer, Odpowiedzialność za zobowiazania ..., s. 290.

7 A. Szpunar, Uwagi o tak zwanej konwersji dtugu, „Rejent” 2000, nr 2, s. 13. 
Rozporządzenie o konwersji i uporządkowaniu długów rolniczych przewidywało jeszcze dwa oryginalne rozwiązania: możliwość zapłaty długów rolniczych papierami wartościowymi i konwersję długów rolniczych na kredyt długoterminowy w listach zastawnych ${ }^{8}$. Z możliwości zapłaty długów rolniczych papierami wartościowymi można było skorzystać w ciągu 3 lat od wejścia w życie rozporządzenia. W tym celu minister skarbu w porozumieniu $\mathrm{z}$ ministrem rolnictwa i reform rolnych oznaczał papiery wartościowe $\mathrm{w}$ drodze rozporządzeń i określał kurs, po którym wierzyciele byli zobowiązani przyjmować te papiery. Papierami wartościowymi można było uregulować nie tylko kapitał długu, ale także odsetki, prowizje, koszty i inne należności uboczne $\mathrm{z}$ tytułu długu. Jednak najciekawszym pod względem prawnym rozwiązaniem była konwersja długów rolniczych na kredyt długoterminowy w listach zastawnych. Istotę tego rozwiązania stanowiło to, że długi rolnicze zabezpieczone hipotecznie mogły być w okresie 3 lat od wejścia w życie rozporządzenia skonwertowane na długu $\mathrm{w}$ 4,5-proc. listach zastawnych, umarzalnych w okresie nie dłuższym niż 55 lat, z tym że należność wierzyciela była spłacana tymi listami po kursie al pari.

Do dokonania konwersji uprawnione były instytucje kredytu długoterminowego, decyzja zapadała na mocy swobodnego uznania tej instytucji, a wniosek o konwersję mógł złożyć dłużnik albo wierzyciel. Akt konwersji sporządzany był przed notariuszem i powinien był zawierać ustanowienie pożyczki w listach zastawnych oraz rozliczenie właściciela nieruchomości $\mathrm{z}$ wierzycielami. Listy zastawne pochodzące $\mathrm{z}$ udzielonej pożyczki wydawane były wierzycielowi długów rolnych przez instytucję dokonującą konwersji. Pożyczka udzielona w listach zastawnych jako efekt konwersji długów rolniczych podlegała zabezpieczeniu hipotecznemu na pierwszym miejscu.

Omawiane rozporządzenie, obok wskazanych wyżej zagadnień związanych z konwersją i uporządkowaniem długów rolniczych, dotyczyło również postępowania układowego i likwidacyjnego. Zakres postępowania układowego był szerszy niż w rozporządzeniu z 1932 r., ponieważ mogli z niego skorzystać zarówno ci dłużnicy długów rolnych, którzy wcześniej korzystali z ulg przewidzianych w ramach konwersji długu, jak i ci dłużnicy, którzy z nich nie korzystali, a zaprzestali płacenia swoich zobowiązań prywatno- lub publicznoprawnych. Tym samym postępowanie układowe nabrało samodzielnego charakteru.

W ustawodawstwie okresu międzywojennego dotyczącego problematyki odpowiedzialności za długi rolne można jeszcze wskazać te akty prawne, które wprowadzały różnego rodzaju ulgi i ułatwienia, ale nie dla osób od-

\footnotetext{
${ }^{8}$ E. Kremer, Odpowiedzialność za zobowiąania..., s. 294.
} 
powiedzialnych z tytułu długów rolnych, lecz dla instytucji kredytowych posiadających wierzytelności rolnicze. Przykładowo można wskazać ustawę z 25 lutego 1932 r. o ulgach kredytowych dla instytucji rolniczych ${ }^{9}$ i ustawę z 24 marca 1933 r. o ułatwieniach dla instytucji kredytowych, przyznających dłużnikom ulgi w zakresie wierzytelności rolniczych ${ }^{10}$.

Aby uzyskać pełny obrazu stanu prawnego z okresu międzywojennego, należy odnieść się jeszcze do ówczesnego prawa upadłościowego z 24 października 1934 r. $^{11}$ i prawa o postępowaniu układowym również z 24 października 1934 r. ${ }^{12}$ Prawo upadłościowe w art. 3 określiło podmioty, w stosunku do których nie można było ogłosić upadłości. Podstawowa kategoria podmiotów, wobec których wyłączona została możliwość ogłoszenia upadłości, to podmioty, które pełniły szczególne role i funkcje publiczne w życiu społeczno-gospodarczym. Jednak wśród podmiotów, w przypadku których wyłączona została możliwość ogłoszenia upadłości, wymienione zostały osoby fizyczne prowadzące gospodarstwo rolne (chyba że osoba fizyczna prowadziła gospodarstwo rolne w większym rozmiarze i uzyskała status kupca rejestrowego).

Natomiast w przypadku, gdy gospodarstwo rolne było przedmiotem działalności osoby prawnej, zdolność upadłościowa istniała. Podobnie wyglądała sytuacja na tle prawa o postępowaniu układowym - osoba fizyczna prowadząca gospodarstwo rolne nie posiadała zdolności układowej, chyba że prowadząc gospodarstwo w większym rozmiarze, uzyskała status kupca rejestrowego. To wyłączenie zdolności układowej na podstawie ogólnych przepisów prawa o postępowaniu układowym z 24 października 1934 r. nie pozbawiało jednak osoby fizycznej prowadzącej gospodarstwo rolne możliwości zawarcia układu, gdyż mogła ona skorzystać ze szczególnego postępowania układowego uregulowanego w powoływanym rozporządzeniu z 24 października 1934 r. o konwersji i uporządkowaniu długów rolniczych, adresowanego wyłącznie do osób prowadzących gospodarstwa rolne.

Powyższe uwagi skłaniają do następujących wniosków: po pierwsze, problematyka prawnej możliwości przekształcenia, konwersji, restrukturyzacji długów rolniczych w związku z uciążliwością tych długów, niewypła-

${ }^{9}$ Ustawa z 25 lutego 1932 r. o ulgach kredytowych dla instytucji rolniczych (Dz. U. Nr 24, poz. 188).

${ }^{10}$ Ustawa z 24 marca 1933 r. o ułatwieniach dla instytucji kredytowych, przyznających dłużnikom ulgi w zakresie wierzytelności rolniczych (Dz. U. Nr 25, poz. 211).

${ }_{11}$ Rozporządzenie Prezydenta Rzeczypospolitej z 24 października 1934 r. - Prawo upadłościowe (Dz. U. 93, poz. 834).

12 Rozporządzenie Prezydenta Rzeczypospolitej z 24 października 1934 r. - Prawo o postępowaniu układowym (Dz. U. Nr 93, poz. 836). 
calnością dłużnika bądź zagrożeniem niewypłacalnością została uregulowana w sposób szczególny, a tym samym wyłączone zostały rozwiązania zawarte w powszechnym prawie upadłościowym i w prawie o postępowaniu układowym; po drugie, w ramach przyjętych rozwiązań szczególnych dotyczących konwersji, restrukturyzacji długów rolniczych ówczesny ustawodawca zastosował różne konstrukcje prawne, tworząc bogaty katalog instrumentów służących oddłużeniu sektora rolnego.

\section{Uwagi dotyczące prawa upadłościowego i prawa restrukturyzacyjnego}

Po II wojnie światowej szczególne ustawodawstwo oddłużeniowe (rolne) przestało obowiązywać, a moc prawną zachowało jedynie powszechne Prawo upadłościowe z 24 października 1934 r. i powszechne Prawo o postępowaniu układowym z 24 października 1934 r. W nowej ustawie z 28 lutego 2003 r. dotyczącej Prawa upadłościowego i naprawczego ${ }^{13}$ utrzymana została dotychczasowa zasada, iż osoba fizyczna prowadząca gospodarstwo rolne nie posiada zdolności upadłościowej, a tym samym nie jest możliwe zawarcie układu i dokonanie restrukturyzacji zobowiązań upadłego. Natomiast restrukturyzacja zobowiązań upadłego mogła obejmować w szczególności: odroczenie wykonania zobowiązań, rozłożenie spłaty długów na raty, zmniejszenie sumy długów, konwersje wierzytelności na udziały lub akcje, jak również zmianę, zamianę lub uchylenie prawa zabezpieczającego określoną wierzytelność (art. 270).

Nowe Prawo upadłościowe i naprawcze regulowało ponadto nieznaną wcześniej instytucję, jaką jest możliwość oddłużenia, która mogła mieć zastosowanie do upadłego będącego osobą fizyczną. Ustawa z 28 lutego $2003 \mathrm{r}$. wprowadziła też nowy rodzaj postępowania - postępowanie naprawcze, które mogło być stosowane do zagrożonych niewypłacalnością przedsiębiorców wpisanych do Krajowego Rejestru Sądowego. Kolejna zmiana stanu prawnego nastąpiła wraz z wejściem w życie ustawy z 15 maja 2015 r. - Prawo restrukturyzacyjne ${ }^{14}$. Głównym założeniem ustawy było wprowadzenie skutecznych instrumentów pozwalających na dokonanie restrukturyzacji przedsiębiorstwa dłużnika i zapobieżenie jego likwidacji.

Praktyka pokazała, że sam fakt ogłoszenia upadłości dłużnika wyklucza możliwość skutecznej restrukturyzacji, niezależnie od tego, czy jest to

${ }^{13}$ Ustawa z 28 lutego 2003 r. - Prawo upadłościowe i naprawcze (Dz. U. Nr 60, poz. 535).

${ }^{14}$ Ustawa z 15 maja 2015 r. - Prawo restrukturyzacyjne (Dz. U. z 2019 r., poz. 243 ze zm.). 
upadłość z możliwością zawarcia układu, czy likwidacyjna. Skojarzenia upadłości z końcem działalności, bankructwem i brakiem możliwości odzyskania swoich wierzytelności są tak silne, że w wielu przypadkach po ogłoszeniu upadłości wierzyciele nie chcą podejmować żadnych rozmów z dłużnikiem. Z tych względów projekt zakłada oddzielenie postępowań restrukturyzacyjnych od stygmatyzujących postępowań upadłościowych ${ }^{15}$. Dla jasności podziału zdecydowano się uregulować postępowania restrukturyzacyjne w osobnej ustawie - Prawo restrukturyzacyjne. W tym zakresie regulacja ta nawiązuje więc do rozwiązań przedwojennych. Ustawa wprowadza cztery postępowania restrukturyzacyjne: a) postępowanie o zatwierdzenie układu, b) przyspieszone postępowanie układowe, c) postępowanie układowe, d) postępowanie sanacyjne. Restrukturyzacja w rozumieniu ustawy (art. 3 ust. 1) oznacza wyłącznie: a) zawarcie układu z wierzycielami, b) w przypadku postępowania sanacyjnego - zawarcie układu z wierzycielami oraz przeprowadzenie działań sanacyjnych, przy zabezpieczeniu słusznych praw wierzycieli. Restrukturyzacja przedsiębiorstwa dotyczy więc głównie zobowiązań, a w znacznie mniejszym stopniu - sposobu zarządzania przedsiębiorstwem. Przewidziane postępowania mają zapewnić możliwość wyboru formy restrukturyzacji dostosowanej do potrzeb konkretnego przedsiębiorstwa w konkretnej sytuacji finansowej.

Zdolność restrukturyzacyjna określa podmiotowy zakres zastosowania ustawy. Jest to przyznana przez ustawodawcę określonym kategoriom podmiotów zdolność do bycia podmiotem postępowania restrukturyzacyjnego, a konkretnie zdolność do występowania w postępowaniu restrukturyzacyjnym w charakterze dłużnika.

Jak słusznie zauważa Anna Hrycaj ${ }^{16}$, zgodnie z art. 3 Prawa restrukturyzacyjnego celem postępowania restrukturyzacyjnego jest uniknięcie ogłoszenia upadłości dłużnika. W świetle tej regulacji powstaje pytanie, czy podmioty, które nie posiadają zdolności upadłościowej, a więc nie grozi im ogłoszenie upadłości, posiadają zdolność restrukturyzacyjną, skoro bezprzedmiotowe jest co do nich podejmowanie działań zmierzających do uniknięcia ogłoszenia upadłości. Według art. 6 Prawa upadłościowego zdolności upadłościowej nie posiadają: Skarb Państwa, jednostki samorządu terytorialnego, publiczne samodzielne zakłady opieki zdrowotnej, instytucje i osoby prawne utworzone w drodze ustawy, chyba że ustawa ta stanowi inaczej, oraz utworzone w wykonaniu obowiązku nałożonego ustawą osoby fizyczne prowadzące gospodarstwo rolne, które nie prowadzą

\footnotetext{
${ }^{15} \mathrm{Z}$ uzasadnienia do projektu ustawy z 15 maja 2015 r. - Prawo restrukturyzacyjne.

${ }^{16}$ P. Filipiak, A. Hrycaj (red.), Prawo restrukturyzacyjne. Komentarz, LEX/el. 2020.
} 
innej działalności gospodarczej lub zawodowej, uczelnie oraz fundusze inwestycyjne ${ }^{17}$.

Przyjęcie, że brak zdolności upadłościowej przesądza o braku zdolności restrukturyzacyjnej, oznaczałoby, że zdolności tej nie miałyby np. posiadające status przedsiębiorcy podmioty utworzone w drodze ustawy czy w wykonaniu obowiązku nałożonego ustawą. Pogląd taki byłby jednak błędny. Należy zauważyć, że w art. 6 Prawa upadłościowego zdolności upadłościowej został pozbawiony np. Skarb Państwa oraz jednostki samorządu terytorialnego. Te same podmioty zostały pozbawione zdolności restrukturyzacyjnej w art. 4 ust. 2 Prawa restrukturyzacyjnego. Gdyby brak zdolności upadłościowej miał przesądzać o braku zdolności restrukturyzacyjnej, wymienienie tych pomiotów w art. 4 ust. 2 Prawa restrukturyzacyjnego byłoby zbędne. Założenie racjonalności ustawodawcy nie pozwala na zaakceptowanie takiego poglądu.

Oznacza to, że zdolność restrukturyzacyjna danego podmiotu nie zależy od tego, czy podmiot ten posiada zdolność upadłościową, a katalog podmiotów, które posiadają zdolność restrukturyzacyjną bądź jej nie posiadają, został w sposób zupełny uregulowany w art. 4 Prawa restrukturyzacyjnego. Zdolność restrukturyzacyjną posiadają przede wszystkim przedsiębiorcy, gdyż zgodnie z art. 4 ust. 1 pkt 1 Prawa restrukturyzacyjnego przepisy ustawy stosuje się do przedsiębiorców w rozumieniu Kodeksu cywilnego. Jak stanowi art. $43^{1}$ k.c., przedsiębiorcą jest osoba fizyczna, prawna oraz jednostka organizacyjna, o której mowa w art. $33^{1}$ k.c., prowadząca we własnym imieniu działalność gospodarczą lub zawodową.

Na tym tle pojawia się pytanie, czy zdolność restrukturyzacyjną posiada rolnik indywidualny, zważywszy, że o ile w prawie upadłościowym ustawodawca jednoznacznie przesądził, że rolnik indywidualny prowadzący gospodarstwo rolne nie posiada zdolności upadłościowej, o tyle w prawie restrukturyzacyjnym pośród wymienionych podmiotów nieposiadających zdolności restrukturyzacyjnej rolnik indywidualny nie został wymieniony. Należy się zatem odwołać do pojęcia przedsiębiorcy w rozumieniu art. $43^{1}$ k.c., zgodnie z którym rolnik indywidualny prowadzący we własnym imieniu działalność wytwórczą w zakresie upraw o wymienionych cechach działalności gospodarczej jest przedsiębiorcą.

Do kategorii tej nie należą rolnicy nieuczestniczący w obrocie gospodarczym, którzy prowadzą gospodarstwo rolne zaspokajające jedynie potrzeby własnej rodziny, wymaganie bowiem uczestnictwa w obrocie polega na

${ }_{17}$ Szerzej: F. Zedler, w: A. Jakubecki, F. Zedler, Prawo upadłościowe i naprawcze. Komentarz, Kraków 2003, s. 33. 
realizowaniu swojej działalności przez odpłatne ekwiwalentne świadczenia wzajemne spełniane za pomocą wielorazowych czynności faktycznych i prawnych. Postępowania restrukturyzacyjne to postępowania cywilne prowadzone przez sądy rejonowe gospodarcze wobec dłużnika niewypłacalnego lub zagrożonego niewypłacalnością. Obowiązująca ustawa z 15 maja 2015 r. - Prawo restrukturyzacyjne ma charakter regulacji ogólnej i nie zawiera żadnych szczególnych rozwiązań dla podmiotów prowadzących gospodarstwa rolne.

\section{Ustawa z 9 listopada 2018 r. o restrukturyzacji zadłużenia podmiotów prowadzących gospodarstwa rolne}

Ustawa o restrukturyzacji zadłużenia podmiotów prowadzących gospodarstwa rolne wprowadza rozwiązania szczególne w stosunku do rozwiązań zawartych w ustawie z 15 maja 2015 r. - Prawo restrukturyzacyjne. Jak zaznaczono na wstępie, powodem wprowadzenia rozwiązań szczególnych był wzrost zaległych zobowiązań podmiotów prowadzących gospodarstwa rolne wobec banków i instytucji finansowych oraz ograniczone możliwości restrukturyzacji zadłużenia na podstawie funkcjonującej ustawy - Prawo restrukturyzacyjne.

Zgodnie z art. 2 ustawy z 9 listopada 2018 r. restrukturyzacją można objąć długi o charakterze pieniężnym powstałe w związku z prowadzeniem działalności rolniczej przez podmiot prowadzący gospodarstwo rolne. Podmioty, które mogą skorzystać z restrukturyzacji, mają następujące cechy: 1) jest to osoba fizyczna, osoba prawna albo jednostka organizacyjna nieposiadająca osobowości prawnej, której ustawa przyznaje zdolność prawną, 2) ma miejsce zamieszkania albo siedzibę na terytorium Rzeczypospolitej Polskiej, 3) jest właścicielem gospodarstwa rolnego w rozumieniu przepisów ustawy z 15 listopada 1984 r. o podatku rolnym ${ }^{18}$, 4) jest małym, średnim lub dużym przedsiębiorstwem w rozumieniu załącznika I do rozporządzenia Komisji (UE) nr 702/2014 z 25 czerwca 2014 r. uznającego niektóre kategorie pomocy w sektorach rolnym i leśnym oraz na obszarach wiejskich za zgodne z rynkiem wewnętrznym w zastosowaniu art. 107 i 108 Traktatu o funkcjonowaniu Unii Europejskiej ${ }^{19}, 5$ ) od co najmniej 3 lat prowadzi działalność rolniczą w rozumieniu przepisów ustawy z 15 listopada 1984 r. o podatku

18 Ustawa z 15 listopada 1984 r. o podatku rolnym (Dz. U. z 2017 r., poz. 1892 oraz z 2018 r., poz. 1588,1669 i 2244$)$.

19 Załącznik I do rozporządzenia Komisji (UE) nr 702/2014 z 25 czerwca 2014 r. uznającego niektóre kategorie pomocy w sektorach rolnym i leśnym oraz na obszarach wiejskich za zgodne 
rolnym (dalej: działalność rolnicza) w gospodarstwie wymienionym w pkt 3 , licząc od dnia powstania wobec tego podmiotu obowiązku podatkowego w zakresie podatku rolnego w odniesieniu do gruntów wchodzących w skład tego gospodarstwa, 6) jest niewypłacalny w rozumieniu przepisów ustawy z 28 lutego 2003 r. - Prawo upadłościowe ${ }^{20}$ albo zagrożony niewypłacalnością w rozumieniu przepisów ustawy z 15 maja 2015 r. - Prawo restrukturyzacyjne ${ }^{21}$.

$\mathrm{Z}$ restrukturyzacji zadłużenia nie mogą natomiast skorzystać podmioty prowadzące gospodarstwo rolne znajdujące się w likwidacji lub w upadłości ani podmioty, wobec których toczy się postępowanie restrukturyzacyjne na podstawie ustawy z 15 maja 2015 r. - Prawo restrukturyzacyjne. Wyznaczony $\mathrm{w}$ ustawie krąg podmiotów uprawnionych do skorzystania $\mathrm{z}$ restrukturyzacji zadłużenia po raz pierwszy został określony bardzo szeroko, gdyż objął zarówno osoby fizyczne, osoby prawne, jak i jednostki organizacyjne nieposiadające osobowości prawnej, ale posiadające zdolność prawną. Do kręgu podmiotów uprawnionych do skorzystania z restrukturyzacji zadłużenia zaliczone zostały również małe, średnie lub duże przedsiębiorstwa w rozumieniu załącznika I do rozporządzenia Komisji (UE) nr 702/2014.

Wskazane podmioty muszą ponadto spełniać te same przesłanki dotyczące zarówno związku z Polską poprzez miejsce zamieszkania lub siedziby, jak i gospodarstwa rolnego i prowadzonej działalności rolniczej. Odwołanie się do definicji gospodarstwa rolnego i działalności rolniczej zawartych w ustawie o podatku rolnym, po pierwsze, sprawia, że ustalenie zakresu tych pojęć nie nastręcza trudności, po drugie, zaważywszy na treść i zakres tych definicji, pozwala spełnić wynikające z nich wymogi, co oznacza, że potencjalny krąg podmiotów chcących skorzystać z restrukturyzacji zadłużenia powstałego $\mathrm{w}$ związku z prowadzeniem działalności rolniczej jest dość szeroki.

Wystarczy bowiem przypomnieć, że w świetle ustawy o podatku rolnym za gospodarstwo rolne uważa się obszar gruntów sklasyfikowanych w ewidencji gruntów i budynków jako użytki rolne (z wyjątkiem gruntów zajętych na prowadzenie działalności gospodarczej innej niż działalność rolnicza) o łącznej powierzchni przekraczającej 1 ha lub 1 ha przeliczeniowy, stanowiących własność lub znajdujących się w posiadaniu osoby fizycznej,

z rynkiem wewnętrznym w zastosowaniu art. 107 i 108 Traktatu o funkcjonowaniu Unii Europejskiej (Dz. Urz. UE L 193 z 1.07.2014 r., s. 1, z późn. zm.; dalej: rozporządzenie nr 702/2014).

${ }^{20}$ Ustawa z 28 lutego 2003 r. - Prawo upadłościowe (Dz. U. z 2017 r., poz. 2344 i 2491 oraz z 2018 r., poz. $398,685,1544$ i 1629).

${ }^{21}$ Ustawa z 15 maja 2015 r. - Prawo restrukturyzacyjne (Dz. U. z 2017 r., poz. 1508 oraz z 2018 r., poz. 149, 398, 1544 i 1629). 
osoby prawnej albo jednostki organizacyjnej, w tym spółki nieposiadającej osobowości prawnej ${ }^{22}$. Tym samym dla uznania określonych gruntów za gospodarstwo rolne nie jest konieczne, aby stanowiły one zorganizowaną całość bądź leżały na obszarze jednej gminy, powiatu czy województwa. Gospodarstwo rolne tworzą bowiem grunty będące własnością lub w posiadaniu jednej osoby, położone na dowolnym obszarze, nawet gdy nie istnieje pomiędzy nimi żadna więź ekonomiczna czy gdy z uwagi na położenie (np. w różnych gminach) nie mogą one stanowić zorganizowanej całości.

$\mathrm{Z}$ definicji gospodarstwa rolnego, wprowadzonej na potrzeby podatku rolnego, wynika, że jedynym elementem łączącym wyżej wymienione grunty jest osoba rolnika. Definicja gospodarstwa rolnego na potrzeby opodatkowania podatkiem rolnym bazuje na powierzchni użytków rolnych. Jeżeli powierzchnia użytków rolnych stanowiących własność lub będących w posiadaniu podatnika przekracza 1 ha fizyczny lub 1 ha przeliczeniowy, to jest to wystarczająca przesłanka do uznania tych użytków za gospodarstwo rolne $^{23}$. Pojęcie gospodarstwa rolnego zawarte w ustawie o podatku rolnym różni się istotnie od definicji gospodarstwa rolnego zawartej w art. $55^{3}$ k.c.

Natomiast za działalność rolniczą uważa się produkcję roślinną i zwierzęcą, w tym produkcję materiału siewnego, szkółkarskiego, hodowlanego i reprodukcyjnego, produkcję warzywniczą, roślin ozdobnych, grzybów uprawnych, sadownictwa, hodowlę i produkcję materiału zarodowego zwierząt, ptactwa i owadów użytkowych, produkcję zwierzęcą typu przemysłowego fermowego oraz chów i hodowlę ryb ${ }^{24}$. Pojęcie działalności rolniczej ustawodawca precyzuje, wskazując na określone rodzaje działalności, przede wszystkim o charakterze produkcyjnym. Znaczenie czynności mieszczących się w pojęciu działalności rolniczej jest istotne dla zakresu przedmiotu opodatkowania tym podatkiem.

Pojęcie to - jak już wskazano - nie ma co prawda wpływu na przyjęcie statusu gospodarstwa rolnego, niemniej jest znaczące dla zakresu przedmiotu opodatkowania. Skoro bowiem ustawodawca poddaje opodatkowaniu grunty sklasyfikowane w odpowiedni sposób i niezajęte na prowadzenie działalności gospodarczej innej niż działalność rolnicza, należy przyjąć, iż uznanie, że dane czynności dotyczące gruntu są jeszcze działalnością rolniczą, a nie gospodarczą, powoduje opodatkowanie ich podatkiem rolnym ${ }^{25}$. Jednak $\mathrm{w}$ analizowanej ustawie o restrukturyzacji zadłużenia podmiotów

${ }^{22}$ Art. 2 ust. 1 ustawy z 15 listopada 1984 r. o podatku rolnym (t.j. Dz. U. z 2020 r., poz. 333).

${ }^{23}$ L. Etel, B. Pahl, M. Popławski, Podatek rolny. Komentarz, LEX/el. 2021.

${ }^{24}$ Art. 2 ust. 2 ustawy z 15 listopada 1984 r. o podatku rolnym (t.j. Dz. U. z 2020 r., poz. 333).

${ }^{25}$ P. Borszowski, Komentarz do ustawy o podatku rolnym, w: idem, Podatek rolny i leśny. Komentarz, Warszawa 2013. 
prowadzących gospodarstwo rolne odwołanie w art. 1 ust. 2 pkt 5 do wymogu prowadzenia co najmniej od 3 lat działalności rolniczej w rozumieniu przepisów o podatku rolnym pełni szczególną rolę, stanowi bowiem jedną z ustawowych przesłanek, która musi być spełniona, aby przeprowadzenie restrukturyzacji zadłużenia było możliwe.

O ile więc pojęcie prowadzenia działalności rolniczej na potrzeby podatku rolnego ma znaczenie przede wszystkim dla ustalenia zakresu przedmiotu opodatkowania, o tyle w przypadku ubiegania się o dokonanie restrukturyzacji zadłużenia przez podmiot prowadzący gospodarstwo rolne konieczne jest prowadzenie działalności rolniczej co najmniej od 3 lat. Ponadto podmiot prowadzący gospodarstwo rolne starający się o przeprowadzenie restrukturyzacji zadłużenia musi być niewypłacalny w rozumieniu ustawy - Prawo upadłościowe lub zagrożony niewypłacalnością w rozumieniu ustawy Prawo restrukturyzacyjne.

Uwagi dotyczące zakresu podmiotów, które mogą skorzystać z restrukturyzacji zadłużenia, prowadzą do następujących wniosków. Po pierwsze, zakres ten został ustalony szeroko, ponieważ obejmuje wszystkie podmioty będące zarówno osobami fizycznymi, osobami prawnymi, jak i jednostkami organizacyjnymi nieposiadającymi osobowości prawnej, po drugie, wymóg bycia właścicielem gospodarstwa rolnego, poprzez odesłanie do ustawy o podatku rolnym, obejmuje gospodarstwa, począwszy od stosunkowo małej powierzchni użytków rolnych, które mogą stanowić własność lub być w posiadaniu podatnika. Z kolei wymóg niewypłacalności lub zagrożenia niewypłacalnością ujęty jest podobnie jak w Prawie upadłościowym i Prawie restrukturyzacyjnym. Z restrukturyzacji zadłużenia nie mogą natomiast skorzystać wskazane wyżej podmioty prowadzące gospodarstwo rolne znajdujące się w likwidacji lub upadłości albo wobec którego toczy się postępowanie restrukturyzacyjne na podstawie przepisów ustawy z 15 maja 2015 r. - Prawo restrukturyzacyjne.

Kolejne zagadnienie dotyczy form prawnych, w jakich może być realizowana restrukturyzacja zadłużenia podmiotów prowadzących gospodarstwa rolne. Na podstawie ustawy z 15 maja 2015 r. - Prawo restrukturyzacyjne restrukturyzację przeprowadza się $\mathrm{w}$ następujących postępowaniach restrukturyzacyjnych: 1) postępowaniu o zatwierdzenie układu, 2) przyspieszonym postępowaniu układowym, 3) postępowaniu układowym, 4) postępowaniu sanacyjnym. Natomiast na podstawie ustawy o restrukturyzacji zadłużenia podmiotów prowadzących gospodarstwa rolne restrukturyzacja może polegać na: 1) udzielaniu przez Agencję Restrukturyzacji i Modernizacji Rolnictwa (dalej: Agencja), podmiotowi prowadzącemu gospodarstwo rolne pomocy publicznej w formie: a) dopłat do oprocentowania kredytu udzielonego przez 
bank na sfinansowanie spłaty zadłużenia powstałego w związku z prowadzeniem działalności rolniczej (dalej: kredyt restrukturyzacyjny), b) udzieleniu pożyczki na sfinansowanie spłaty zadłużenia powstałego w związku z prowadzeniem działalności rolniczej (dalej: pożyczka); 2) udzielaniu przez Krajowy Ośrodek Wsparcia Rolnictwa (KOWR) podmiotowi prowadzącemu gospodarstwo rolne pomocy publicznej w formie gwarancji zabezpieczającej spłatę kredytu restrukturyzacyjnego; 3) przejęciu przez KOWR długu podmiotu prowadzącego gospodarstwo rolne powstałego w związku z prowadzeniem działalności rolniczej pod warunkiem przeniesienia własności całości albo części nieruchomości rolnej na rzecz Skarbu Państwa.

Z przedstawionych rozwiązań wynika, że restrukturyzacja zadłużenia podmiotów prowadzących gospodarstwa rolne ma odmienny charakter prawny niż restrukturyzacja prowadzona na podstawie ustawy - Prawo restrukturyzacyjne. Klasyczne postępowania restrukturyzacyjne uregulowane w tej ustawie prowadzone są przez sąd restrukturyzacyjny, a sądem restrukturyzacyjnym jest sąd rejonowy - wydział gospodarczy ${ }^{26}$. Natomiast formy restrukturyzacji zadłużenia podmiotów prowadzących gospodarstwa rolne polegające na udzieleniu dopłat do oprocentowania kredytów bankowych, zawarciu umowy pożyczki na spłatę zadłużenia, realizowane przez Agencję oraz możliwość zawarcia z KOWR umowy gwarancji zabezpieczającej spłatę kredytu restrukturyzacyjnego stanowią formę pomocy publicznej.

Dlatego konieczne było, aby przyjęty program pomocy został notyfikowany w Komisji Europejskiej jako zgodny z wytycznymi Komisji Europejskiej co do pomocy państwa na ratowanie i restrukturyzację przedsiębiorstw niefinansowych znajdujących się w trudnej sytuacji ${ }^{27}$. Na podstawie art. 8 ustawy o restrukturyzacji zadłużenia podmiotów prowadzących gospodarstwa rolne i decyzji Komisji Europejskiej z 8 kwietnia 2020 r. o zgodności programu pomocy państwa na restrukturyzację zadłużenia gospodarstw rolnych ${ }^{28} \mathrm{z}$ rynkiem wewnętrznym na mocy art. 107 ust. 3 lit. c Traktatu o funkcjonowaniu Unii Europejskiej sukcesywnie uruchamiana jest dla niewypłacalnych lub zagrożonych niewypłacalnością podmiotów prowadzących gospodarstwa rolne pomoc finansowa we wskazanych wyżej formach.

Formy pomocy polegające na udzielaniu dopłat do oprocentowania bankowych kredytów na restrukturyzację zadłużenia, pożyczek na spłatę zadłużenia oraz gwarancji spłaty zadłużenia będą uwarunkowane przedstawieniem przez wnioskodawcę, tj. podmiot prowadzący gospodarstwo rolne,

${ }^{26}$ Art. 14 ustawy z 15 maja 2015 r. - Prawo restrukturyzacyjne (Dz. U. z 2019 r., poz. 243 ze zm.).

27 Pomoc państwa na ratowanie i restrukturyzację przedsiębiorstw niefinansowych znajdujących się w trudnej sytuacji (Dz. Urz. UE C 249 z 31.07.2014 r., s. 1).

${ }^{28}$ Pomoc na restrukturyzację zadłużenia gospodarstw rolnych, SA.56408(2020/N). 
planu restrukturyzacji gospodarstwa rolnego zaakceptowanego przez właściwego ze względu na miejsce położenia gospodarstwa rolnego dyrektora wojewódzkiego ośrodka doradztwa rolniczego. W planie restrukturyzacji gospodarstwa rolnego określona będzie kwota kredytu lub pożyczki niezbędna do odzyskania płynności finansowej, zapewniająca długotrwałą zdolność gospodarstwa rolnego do konkurowania na rynku rolnym.

Opracowanie i realizacja planu restrukturyzacji wynika z wytycznych Komisji Europejskiej co do pomocy państwa na ratowanie i restrukturyzację przedsiębiorstw niefinansowych znajdujących się w trudnej sytuacji. Ocena dyrektora wojewódzkiego ośrodka doradztwa rolniczego w zakresie realności wykonania planu restrukturyzacji, którego efektem ma być odzyskanie płynności finansowej gospodarstwa rolnego, będzie dokonywana na podstawie dostępnych danych ekonomicznych o gospodarstwach rolnych prowadzących produkcję rolną na obszarze działania wojewódzkiego ośrodka doradztwa rolniczego.

Wsparcie podmiotów prowadzących gospodarstwa rolne we wskazanych wyżej przypadkach, które mają formę pomocy publicznej, umożliwia im spłatę zadłużenia bez zgody wierzycieli na jego restrukturyzację, gdyż przeprowadzona w ten sposób restrukturyzacja nie wpływa na sytuację prawną wierzycieli i nie powoduje zmniejszenia ich wierzytelności, a tym samym zmniejszenia kwot długu do spłaty.

Zupełnie odmienny charakter prawny ma natomiast forma restrukturyzacji zadłużenia podmiotów prowadzących gospodarstwa rolne określona $\mathrm{w}$ art. 3 ust. 1 pkt 3 ustawy, polegająca na przejęciu przez KOWR długu podmiotu prowadzącego gospodarstwo rolne pod warunkiem przeniesienia własności całości albo części nieruchomości rolnej na rzecz Skarbu Państwa. Szczegółowa regulacja dotycząca tej formy restrukturyzacji zadłużenia zawarta jest w art. 7 ustawy. Przejęcie przez KOWR długu podmiotu prowadzącego gospodarstwo rolne powstałego $\mathrm{w}$ związku z prowadzeniem działalności rolniczej następuje za zgodą wierzycieli, pod warunkiem przeniesienia przez ten podmiot własności całości albo części nieruchomości rolnej wchodzącej w skład gospodarstwa rolnego prowadzonego przez ten podmiot na rzecz Skarbu Państwa.

Umowa przejęcia długu zawierana jest $\mathrm{w}$ terminie 60 dni od dnia złożenia wniosku przez podmiot prowadzący gospodarstwo rolne. Natomiast w terminie 30 dni od dnia zawarcia umowy o przejęcie długu podmiot prowadzący gospodarstwo rolne zobowiązany jest złożyć zgodę wierzycieli na przejęcie długu, a zawarcie umowy przenoszącej własność nieruchomości rolnej określonej w umowie przejęcia długu następuje w terminie 30 dni od uzyskania zgody wierzycieli. Jeżeli we wskazanym terminie podmiot pro- 
wadzący gospodarstwo rolne nie złoży zgody wierzycieli na przejęcie długu bądź nie zawrze umowy przenoszącej własność nieruchomości określonej w umowie przejęcia długu, to KOWR odstąpi od umowy przejęcia długu. Warto dodać, że przejęty dług nie może przekraczać wartości nieruchomości rolnej, której własność jest przenoszona na rzecz Skarbu Państwa, pomniejszonej o wysokość sumy hipoteki ustanowionej na tej nieruchomości. Nieruchomość rolna, której własność została przeniesiona na rzecz Skarbu Państwa, wchodzi w skład Zasobu Własności Rolnej Skarbu Państwa, którym gospodaruje KOWR. Ustawodawca wprowadził też dodatkowe rozwiązanie, na podstawie którego po przeniesieniu własności nieruchomości rolnej na rzecz Skarbu Państwa w związku z przejęciem długu dotychczasowy właściciel może skorzystać z pierwszeństwa do: 1) dzierżawy tej nieruchomości, 2) dzierżawy tej nieruchomości z zapewnieniem dzierżawcy prawa kupna przedmiotu dzierżawy najpóźniej z upływem okresu, na jaki została zawarta umowa dzierżawy, 3) nabycia tej nieruchomości po upływie co najmniej 5 lat od dnia przeniesienia na rzecz Skarbu Państwa własności tej nieruchomości. Ponadto nieruchomość taka nie może zostać zbyta przed upływem 20 lat od dnia przeniesienia własności, z wyłączeniem zbycia na rzecz dotychczasowego właściciela na jego wniosek.

Wskazana forma restrukturyzacji zadłużenia podmiotów prowadzących gospodarstwo rolne, polegająca na przejęciu długu przez KOWR na podstawie umowy zawartej z dłużnikiem, jest cywilistyczną instytucją uregulowaną w art. 519 i n. k.c. prowadzącą do zmiany dłużnika. Na jej podstawie dochodzi do zmiany osoby po stronie zobowiązanej. Dotychczasowy dłużnik zostaje zwolniony ze zobowiązania, a przejemca staje się dłużnikiem. Instytucja ta może być bardzo pomocna w obrocie - wierzyciel po drugiej stronie stosunku zobowiązanego będzie miał osobę gwarantującą swoim majątkiem lub przymiotami lepsze wypełnienie zobowiązania, a dłużnik po przejęciu długu będzie zwolniony z obowiązku. O takim charakterze przesądził sam ustawodawca, stanowiąc, że do przejęcia przez KOWR długu podmiotu prowadzącego gospodarstwo rolne powstałego w związku z prowadzeniem działalności rolniczej stosuje się przepisy Kodeksu cywilnego dotyczące zmiany dłużnika za zgodą wierzyciela, z tym że nie stosuje się art. 519 $\S 2$ pkt $2 \mathrm{w}$ zakresie, w jakim przepis ten przewiduje bezskuteczność oświadczenia wierzyciela.

Zgodnie z powołanym art. 519 § 2 pkt 2 k.c. przejęcie długu może nastąpić przez umowę między dłużnikiem a osobą trzecią za zgodą wierzyciela; oświadczenie wierzyciela może być złożone którejkolwiek ze stron; jest ono bezskuteczne, jeżeli wierzyciel nie wiedział, że osoba przejmująca dług jest niewypłacalna. Natomiast w przypadku, gdy przejęcie długu dokonywane 
jest jako restrukturyzacja zadłużenia na podstawie ustawy o restrukturyzacji zadłużenia podmiotów prowadzących gospodarstwo rolne, a przejmującym dług jest KOWR, wierzyciel nie może powoływać się na bezskuteczność swojego oświadczenia zawierającego zgodę na przejęcie długu. To wyłączenie nie zmienia istoty tej formy restrukturyzacji zadłużenia, która jest cywilistyczną formą zmiany dłużnika następującą na podstawie umowy.

\section{Uwagi końcowe}

Przedstawione uwagi dotyczące istoty rozwiązań zawartych w ustawie z 9 listopada 2018 r. o restrukturyzacji zadłużenia podmiotów prowadzących gospodarstwa rolne nasuwają następujące wnioski. Po pierwsze, rozwiązania przyjęte w tej ustawie mają charakter szczególny, ponieważ adresowane są tylko do określonego kręgu podmiotów (podmiotów prowadzących gospodarstwo rolne), a także nie dotyczą wszystkich długów, tylko długów pieniężnych powstałych w związku z prowadzeniem gospodarstwa rolnego. Tak określony zakres podmiotowy i przedmiotowy ustawy z 9 listopada $2018 \mathrm{r}$. o restrukturyzacji zadłużenia podmiotów prowadzących gospodarstwa rolne sprawia, że można znaleźć wspólne cechy regulacji przewidzianej w tej ustawie i rozwiązań zawartych w rozporządzeniu Prezydenta RP z 24 października 1934 r. o konwersji i uporządkowaniu długów rolniczych ${ }^{29}$, zaliczanym wówczas do ulgowego ustawodawstwa rolniczego.

Po drugie, w regulacjach zawartych w ustawie z 9 listopada $2018 \mathrm{r}$. i w ustawie z 15 maja 2015 r. - Prawo restrukturyzacyjne, pomimo pozornej zbieżności, brakuje wspólnych czy nawet podobnych rozwiązań. W aktach tych zostały przyjęte odmienne unormowania dotyczące trybu, formy, charakteru prawnego podejmowanych działań restrukturyzacyjnych. Restrukturyzacja zadłużenia podmiotów prowadzących gospodarstwa rolne dokonywana na podstawie ustawy z 9 listopada 2018 r. może przybrać formę prawną pomocy publicznej lub cywilistycznej instytucji przejęcia długów, a nie postępowań restrukturyzacyjnych prowadzonych przez sąd restrukturyzacyjny, którym jest sąd rejonowy gospodarczy, a uregulowanych w ustawie z 15 maja 2015 r. - Prawo restrukturyzacyjne. Natomiast celem obu wymienionych aktów jest niewątpliwie dążenie do poprawy sytuacji prawnej dłużnika, który jest niewypłacalny lub zagrożony niewypłacalnością.

${ }^{29}$ Rozporządzenie Prezydenta RP z 24 października 1934 r. o konwersji i uporządkowaniu długów rolniczych (Dz. U. Nr 94, poz. 841). 


\title{
BIBLIOGRAFIA
}

Borszowski P. (2013), Komentarz do ustawy o podatku rolnym, w: idem, Podatek rolny i leśny. Komentarz, Warszawa.

Etel L., Pahl B., Popławski M. (2021), Podatek rolny. Komentarz, LEX/el.

Filipiak P., Hrycaj A. (red.) (2020), Prawo restrukturyzacyjne. Komentarz, LEX/el.

Jakubecki A., Zedler F. (2003), Prawo upadłościowe i naprawcze. Komentarz, Kraków.

Kremer E. (2004), Odpowiedzialność za zobowiązania związane z prowadzeniem gospodarstwa rolnego, Kraków.

Szpunar A. (2000), Uwagi o tak zwanej konwersji dtugu, „Rejent” nr 2.

\section{RESTRUCTURING THE DEBT OF FARM OPERATORS}

\section{Summary}

On 8 February 2019, the Act of 9 November 2018 on restructuring debts of entities running agricultural holdings entered into force. This law contains special solutions enabling partial settlement of debts taken up in relation to their agricultural activities. The reason for the introduction of special solutions was the increase in outstanding liabilities of farm operators towards the banks and financial institutions and the limited possibilities of farmers to restructure their debts under the existing provisions of the Act of 15 May 2015 - Restructuring Law. This Act contains, for the first time, a broad definition of the entities entitled to benefit from debt restructuring. That definition includes natural persons, legal persons, and organisational units without legal personality but with legal capacity, as well as small, medium-sized and large enterprises within the meaning of Annex I to the Commission Regulation (EU) No 702/2014. Debts that may be subject to restructuring are debts of monetary nature incurred in connection with an at least 3-year agricultural activity conducted by a farm operator who resides in Poland or whose registered office in the territory of the Republic of Poland, who is insolvent or threatened with insolvency.

Keywords: insolvency law, restructuring law, restructuring of debts of farm operators, public aid, taking over of debts

\section{SULLA RISTRUTTURAZIONE DEL DEBITO NEI CONFRONTI DEI SOGGETTI CHE CONDUCONO UN'AZIENDA AGRICOLA}

\author{
Riassunto
}

L'8 febbraio 2019 è entrata in vigore la legge del 9 novembre 2018 sulla ristrutturazione del debito nei confronti dei soggetti che conducono un'azienda agricola. L'atto contiene soluzioni specifiche che consentono di poter estinguere parzialmente il debito derivato dall'esercizio dell'attività agricola. Le soluzioni ivi contenute sono state proposte in quanto le passività scadute dei soggetti in questione nei confronti di banche e istituzioni finanziarie 
erano in aumento, mentre le possibilità di ristrutturare il debito grazie alla legge del 15 maggio 2015 "Prawo restrukturyzacyjne" (Legge sulla ristrutturazione) limitate. Il gruppo di soggetti legittimati ad avvalersi della ristrutturazione del debito, specificato nella legge del 9 novembre 2018, è stato definito per la prima volta in modo molto ampio in quanto comprendeva sia le persone fisiche, le persone giuridiche, sia le unità organizzative prive di personalità giuridica, ma dotate di capacità giuridica. Il gruppo comprendeva anche le piccole, medie e grandi imprese ai sensi dell'allegato I del regolamento (UE) n. 702/2014. La ristrutturazione può coprire i debiti di natura pecuniaria derivanti dall'esercizio dell'attività agricola svolto per almeno 3 anni da un soggetto che conduce un'azienda agricola, con la residenza o la sede nel territorio della Repubblica di Polonia, ed è insolvente o soggetto a rischio di insolvenza. Per contro, la ristrutturazione in oggetto effettuata ai sensi della legge del 9 novembre 2018 può assumere la forma giuridica di un aiuto pubblico che consiste nel concedere contributi al tasso d'interesse sul prestito, il prestito, o la garanzia del mutuo oppure l'istituto civilistico di rilevamento del debito a condizione che la proprietà di beni agricoli venga trasferita a favore del Tesoro di Stato. Pertanto, la ristrutturazione del debito effettuata sulla base della legge del 9 novembre 2018 non equivale a procedura di ristrutturazione condotta da un tribunale distrettuale - tribunale del commercio, come avviene ai sensi della legge del 15 maggio 2015 "Prawo restrukturyzacyjne" (Legge sulla ristrutturazione).

Parole chiave: diritto fallimentare, diritto di ristrutturazione, ristrutturazione dei soggetti che gestiscono un'azienda agricola, aiuti pubblici, rilevamento del debito 